\title{
Review
}

\section{Overview of Sources and Characteristics of Nanoparticles in Urban Traffic-Influenced Areas}

\author{
Topi Rönkkö ${ }^{\mathrm{a}, *}$ and Hilkka Timonen ${ }^{\mathrm{b}}$ \\ ${ }^{a}$ Aerosol Physics Laboratory, Physics Unit, Tampere University, Tampere, Finland \\ ${ }^{\mathrm{b}}$ Atmospheric Composition Research, Finnish Meteorological Institute, Helsinki, Finland
}

Accepted 24 August 2019

\begin{abstract}
Atmospheric nanoparticles can be formed either via nucleation in atmosphere or be directly emitted to the atmosphere. In urban areas, several combustion sources (engines, biomass burning, power generation plants) are directly emitting nanoparticles to the atmosphere and, in addition, the gaseous emissions from the same sources can participate to atmospheric nanoparticle formation. This article focuses on the sources and formation of nanoparticles in traffic-influenced environments and reviews current knowledge on composition and characteristics of these nanoparticles. In general, elevated number concentrations of nanoparticles are very typically observed in traffic-influenced environments. Traffic related nanoparticles can originate from combustion process or from non-exhaust related sources such as brake wear. Particles originating from combustion process can be divided to three different sources; 1) primary nanoparticles formed in high temperature, 2) delayed primary particles formed as gaseous compounds nucleate during the cooling and dilution process and 3) secondary nanoparticles formed from gaseous precursors via the atmospheric photochemistry. The nanoparticles observed in roadside environment are a complex mixture of particles from several sources affected by atmospheric processing, local co-pollutants and meteorology.
\end{abstract}

Keywords: Air quality, traffic, nanoparticles, particle emissions

\section{INTRODUCTION}

In addition to climate and air quality influences, several studies have indicated that particulate matter (PM) pollution, and specifically the smaller fraction of particles, PM2.5 fraction (particles with a diameter $<2.5 \mu \mathrm{m}$ ) and nanoparticles, frequently defined as particles smaller than $100 \mathrm{~nm}$ in size, has been repeatedly found as the most harmful part of air pollution (e.g., [1-5]). Globally the PM has been estimated to lead to over 3.3. million premature deaths

\footnotetext{
${ }^{*}$ Correspondence to: Topi Rönkkö, Aerosol Physics Laboratory, Physics Unit, Tampere University, (Korkeakoulunkatu 3), Tampere, FI33720, Finland. Tel.: +358 40198 1019; E-mail: topi.ronkko@tuni.fi.
}

and significant costs annually [6] and it has been associated with large variety of different diseases, including acute lower respiratory illness, cerebrovascular disease, ischemic heart disease, COPD, and lung cancer [1-3]. Recently several studies have also indicated that PM has influences to brains. A population-based cohort study conducted in Taiwan found a link between long-term exposure to PM2.5 and the increasing risk of Alzheimer's disease [7]. Cacciottolo et al. [8] combined results from an air pollution neuroepidemiologic study of older women and inhalation neurotoxicological experiments with mice to show that the airborne PM has contribution to neurodegenerative changes, with a potentially greater impact on individuals that have higher risk of Alzheimer's disease ( $A P O E \varepsilon 4$ carriers). 
It is known that nanoparticles are efficiently deposited into the human respiratory system, but the deposition efficiencies are not uniform with respect to particle size. While the nanoparticles larger than $\sim 10 \mathrm{~nm}$ are deposited most efficiently into the alveolar region of the respiratory system, the smallest particles are deposited most efficiently to head airways [9]. These areas contain potential paths for air pollution compounds deposited to the epithelium to be transported to the central nervous system, such as the olfactory bulb [10]. Maher et al. [11] suggested that the combustion-originated nanoparticles of inhaled air can penetrate to the human brain through the olfactory bulb and cause Alzheimer's disease and other brain diseases. Several studies have focused on the link between nanoparticles and Alzheimer's disease. Kim et al. [12] observed that exposure to nickel nanoparticles led to rapid doubling of amyloid- $\beta(A \beta)_{40}$ and $A \beta_{42}$ levels in brains of mice. The link between air pollution and Alzheimer's disease is supported by the observation of PlascenciaVilla et al. [13] who found that magnetite particles, which are toxic to brain tissue via its propensity to generate reactive oxygen species, were directly associated with Alzheimer's disease-related $A \beta$ plaques. Also, Cacciottolo et al. [8] observed in laboratory experiments with female mice that the chronic exposure to nanosized PM, a neurotoxic subfraction of PM2.5, increased both the cerebral $A \beta$ plaque load and neurotoxic $A \beta$ oligomers. The air pollution from traffic has also been associated with decreased cognitive function in older men $[14,15]$ and, furthermore, Oudin et al. [16] reported associations between dementia incidence and local traffic pollution. However, they could not rule out environmental factors such as noise generated by traffic from their results.

The particle size distribution of urban atmospheric aerosols varies significantly depending on location, local weather conditions, and prevailing particle sources. Typically, the size distribution consists of separate particle modes, formed by particles with similar formation and transformation processes or sources. The largest mode, coarse particle mode, contains typically relatively large mechanically generated particles (with diameter typically larger than $1 \mu \mathrm{m}$ ), originated from road dust or tire debris. The accumulation mode of particle size distribution $(100 \mathrm{~nm}>$ diameter $>1.0 \mu \mathrm{m})$ is linked especially with aged, long-range transported aerosol and soot particle emissions. Ultrafine particles (diameter $<100 \mathrm{~nm}$, thus somehow equal to nanoparticles) are typically either directly emitted from combustion sources or formed in the atmosphere; the ultrafine particle size range include typically the nucleation mode (mean diameter typically smaller than $50 \mathrm{~nm}$ ) formed by atmospheric nucleation of particles or from direct anthropogenic nanoparticle emissions [17] and Aitken mode in particle sizes $20-100 \mathrm{~nm}$ [18]. Furthermore, recent studies indicated that the nanoclusters, i.e., extremely small particles (particle diameter smaller than $3 \mathrm{~nm}$ ), can form a separate mode to particle size distribution of urban trafficinfluenced air [19, 20]. Together with surrounding gaseous compounds, the ambient particles form an aerosol that is, especially in urban areas, a complex mixture of particles with different particle sizes and chemical and physical characteristics (e.g., [21-23]), having a potential to transform in the atmosphere as a result of chemical reactions [24, 25] and aerosol dynamics $[26,27]$.

Nanoparticles are frequently defined as particles smaller than $100 \mathrm{~nm}$ in diameter, although other definitions and related discussion exist in the scientific literature [28]. Because of the relatively small mass concentrations of these particles (see Fig. 3 in [29]), the nanoparticles are typically characterized by their particle number concentrations or particle number size distributions. Due to their small mass concentration, composition analysis of nanoparticles is very challenging and the composition of nanoparticles of ambient air, especially in the smallest particle sizes, remains poorly characterized. Elevated nanoparticle number concentrations are very typically observed in urban air [29, 30]. Particularly in traffic-influenced environments, the nanoparticle concentrations can be high, reaching even concentrations higher than $10^{5}$ $\mathrm{cm}^{-1}[29,30]$.

Nanoparticles are directly emitted to urban air by various combustion processes. They are known to be emitted by vehicles and engines, i.e., by passenger cars, diesel trucks and buses, and mobile motor-powered machines (e.g., [31-36]). Residential heating based on the combustion of wood emits them also [37]. Nanoparticles have been observed from emissions of large-scale coal-based production of heat and power [38, 39], from combustion of heavy fuel oil and light fuel oil [40], and from flue gases from industry [30]. Vehicles' brakes represent a potentially significant non-combustion nanoparticle source $[41,42]$. In addition to direct emissions, nanoparticles can also be formed in the atmosphere, from gaseous compounds originated both from natural (e.g., [43] and references therein) and anthropogenic sources (see [44]). Ambient nanopar- 
ticle concentrations in urban environments can have significant spatial and temporal variation. This is due to several reasons. Firstly, the technologies used in motor vehicles vary a lot depending on geographical areas; mostly the emissions of vehicle and engines are regulated at a national level, and although the nanoparticle emissions themselves are not directly regulated by any emission limit in the world, several regulations set for gaseous and particulate emissions (e.g., Euro 5/6 standards (Regulation (EU) 715/2007) and Non-Road Mobile Machinery (NRMM) Regulation, (Regulation (EU) 2016/1628)) have effects on nanoparticle emissions. Secondly, nanoparticle emissions are linked with intensity of human activities; traffic volumes typically increase in the morning and follows the pattern that is somehow specific for each road or environment (e.g., [20]). Similarly, residential heating follows the needs of residents and climatic conditions, resulting in higher emissions in wintertime. Instead, the emissions from large scale power plants can be relatively stable, at least regarding the primary particle emissions from power production. Thirdly, nanoparticle concentrations can be affected by local weather conditions such as wind direction and wind speed, relative humidity, temperature, and by concentrations of other pollutants (see [45]).

Ambient PM2.5 concentrations (i.e., mass concentrations of particles smaller than $2.5 \mu \mathrm{m}$ in aerodynamic diameter) are typically so strongly dominated by the particles larger than $100 \mathrm{~nm}$ that they cannot be used directly as an indicator of nanoparticle concentrations. However, PM2.5 concentrations are typically used in studies focusing on the effect of ambient particulate matter on human health (e.g., [6]), leading to the current situation where the role of ambient nanoparticle concentrations in respect to human population health is relatively unclear. The situation is further complicated due to lack of information on nanoparticle composition, especially regarding the nanoparticles from anthropogenic origin.

Motor traffic has been recognized to be a major source of nanoparticles in urban areas. Due to that, this review focuses on nanoparticles from traffic. This approach is supported by the close vicinity of motor traffic emissions with people; traffic nanoparticle emissions take place at the height of breathing and in environments typically occupied by people, the emitted nanoparticles can enter car cabins [46] and penetrate many typical filter media used in ventilation systems of buildings [47]. However, the effects of traffic on ambient nanoparticle concentrations and characteristics are complex, including the effects of vehicle technologies, driving situations, and weather conditions. In addition, several dynamic processes affect the nanoparticle emissions and particle formation, transportation, and transformation after the emissions, all affecting the exposure of people on nanoparticles in traffic-influenced environments (see Fig. 1). From different perspectives, other reviews regarding the topic include Morawska et al. [48], Gieschaskiel et al. [49], Kumar et al. [50], Brines et al. [17], and Kumar et al. [51].

\section{PRIMARY NANOPARTICLES OF VEHICLE EXHAUST}

The hot and undiluted motor vehicle exhaust typically contains large number of nanoparticles. In general, the nanoparticle number concentration in tailpipe aerosol can be as high as $10^{7}-10^{9} \mathrm{~cm}^{-1}$. Exhaust is shown to include nanoparticles with different sizes, physical characteristics, and chemical compositions. In many studies, the tailpipe particle size distribution has been reported to consist of distinctive particle modes, due to different formation mechanisms and characteristics of particles. The particle mode associated with smaller mean diameter of particles, called either nano or core particle mode, has typically mean particle size smaller than $10 \mathrm{~nm}$ and the larger mode, called either soot or accumulation mode, has particles with diameters from $10 \mathrm{~nm}$ to several hundreds of nanometers, with mean particle size typically in $30-100 \mathrm{~nm}[35,52-57]$.

The core particles of hot and undiluted exhaust have different characteristics and different existence in the exhaust compared to larger soot mode particles. These particles have been called core particles firstly due to their small particle size and tendency to increase in size already in the tailpipe [57] and especially in cooling dilution of exhaust [52] and, secondly, because of the general need to separate them from soot particles. The chemical composition of the core particles has not been totally solved; some studies indicate that the core particles consist of amorphous carbonaceous compounds [57, 58], while other studies indicate that they consist of metallic ash compounds from fuel and lubricant oil $[59,60]$. Because the core particles form at elevated temperatures and are highly non-volatile $[35,52,54$, 55], their life-time in the atmosphere (and possibly in human body) can be longer than the nanoparticles formed in atmospheric conditions from semivolatile 


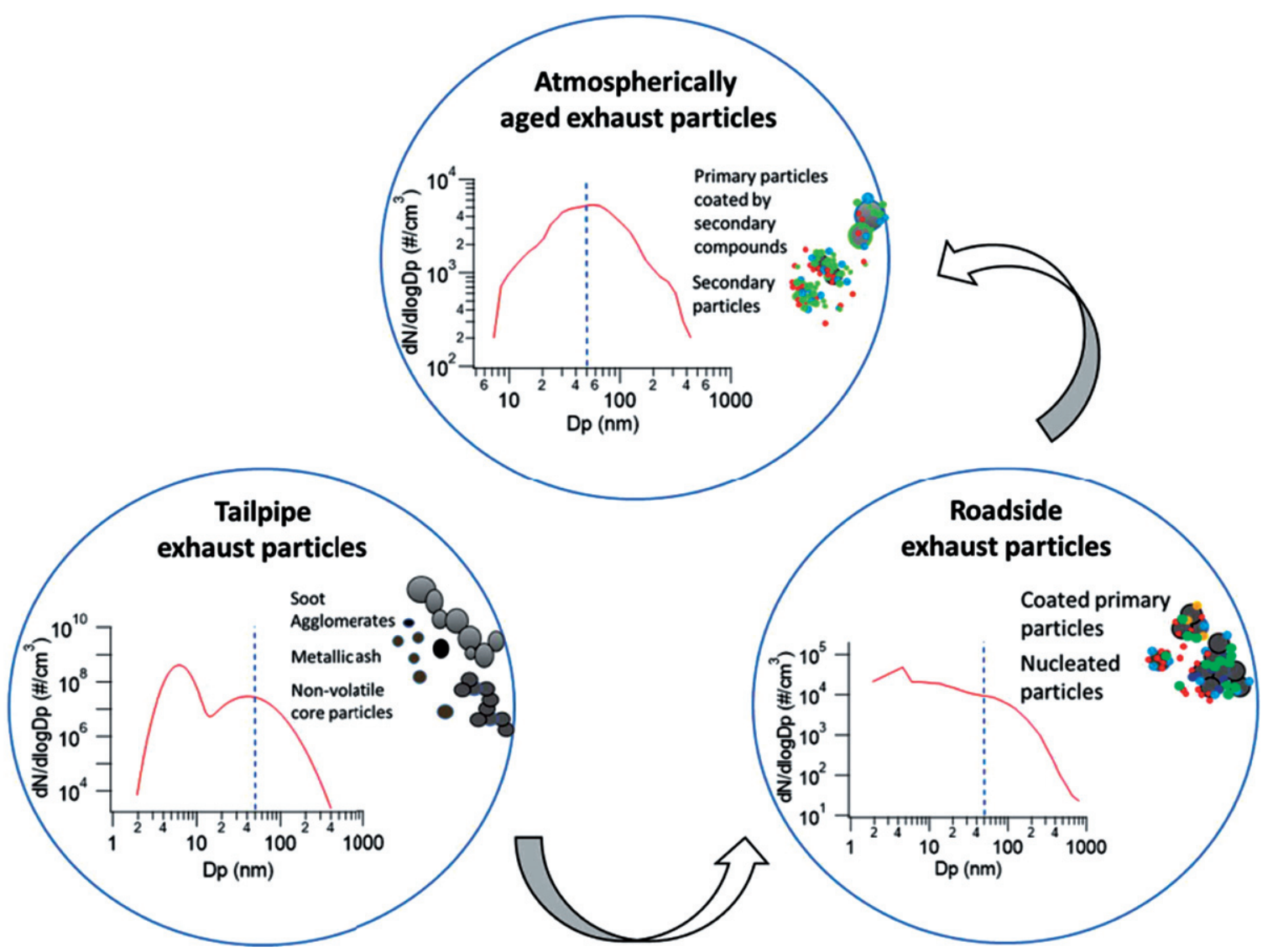

Fig. 1. Schematic regarding differences in particles of tailpipe, roadside, and aged exhaust aerosol. To guide the eye and to emphasize the role of nanoparticles, $50 \mathrm{~nm}$ particle size is indicated by dashed line in the tailpipe exhaust particle size distribution [52], roadside particle size distribution [22], and in the schematic size distribution of aged exhaust aerosol.

and volatile precursors. It should be noted that the tiny and nonvolatile core particles have been observed in the exhaust of different types of engines, including diesel [52, 54], gasoline [57], and natural gas fueled engines [35], so they can be relatively ubiquitous in urban traffic-influenced atmosphere. Furthermore, if the core particles do not coagulate in the atmosphere with larger particles or increase in size significantly by atmospheric condensation of semi-volatile compounds, they deposit efficiently to the upper part of human respiratory tract during inhalation.

Soot particles are mostly agglomerated chain-like particles, but spherical soot particles can also exist in exhaust, especially in the smallest particle sizes (see $[53,61])$. They consist mainly of elemental carbon but also some metallic components can exist in these particles. Exhaust soot particle concentration can be affected by fuel choices or fuel injection strategies $[56,62]$. Interestingly, in several studies conducted on diesel engine exhaust particles, the technology changes reducing the soot particle concentrations have increased the emissions of tiny core particles [56, 62-64]. These changes may also have effects on health risks caused by exhaust particulate matter.

Exhaust particles are typically linked with combustion processes [65]. However, motor vehicle exhaust can also contain particles during motoring conditions (i.e., engine braking conditions) when the fuel injection and combustion process do not take place in the cylinder [66, 67]. Also, these particles have been observed to be mostly in the nanoparticle size range. They are known to contain at least phosphorus, zinc, and calcium, which are most likely originated from lubricant oil additives. In addition, engine wearing can result in the existence of metallic nanoparticles in exhaust [68]. Also, non-exhaust sources of traffic have been shown to emit nanoparticles. For instance, Puisney et al. [69] observed that brake wear dust contains substantial quantities of metallic nanoparticles exhibiting toxicity for lung cells. 
The hot and undiluted exhaust particles are affected by driving conditions of the vehicle and the technological parameters used in vehicles, e.g., the fuel injection type, fuel injection timing and pressure [62], use of exhaust gas recirculation [54], fuel properties $[56,70]$, lubricant oil properties and exhaust aftertreatment such as diesel oxidation catalyst, selective catalytic reduction [71], diesel particle filter (DPF) [72], and partial DPF [73]. For example, the study by De Filippo and Maricq [54] observed in exhaust of a light duty diesel vehicle a clear core particle mode, that was highly dependent on the level of exhaust gas recirculation at idle and at speeds below $30 \mathrm{mph}$. Higher fuel injection pressures and metallic additives of lubricant oil have been observed to increase the concentrations of core particles. Instead, blending gasoline with ethanol [74], use of gaseous fuel instead of liquid fuel [35], and, especially, installing the DPF into the tailpipe [72] significantly reduces nanoparticle emissions of vehicles and engines. The utilization of different technologies in motor vehicles depend on the application area of vehicle but especially on the emission standards. Because the standards are not uniform across the world, the technological approaches utilized in motor vehicles differs from one geographical area to other, likely leading to significant differences in primary nanoparticle emission.

\section{DELAYED PRIMARY PARTICLE FORMATION MODIFIES NANOPARTICLE EMISSIONS}

In addition to particles, the hot and undiluted engine exhaust contains gaseous compounds that tend to condense on particle surfaces or nucleate and form new particles when the initially hot exhaust is diluted and cooled in the atmosphere [33,75-77]. These processes take place in a few seconds in the exhaust plume, potentially modifying the exhaust particle size distribution and resulting in an increased number of nanoparticles [31, 32, 78]. Typically, the roles of these processes are studied in vehicle and engine laboratories using exhaust sampling and dilution setups mimicking the real cooling and dilution of vehicular exhaust, or on the road for individual vehicles by chasing them with a mobile laboratory equipped with particle measurement instruments (for examples, see $[31,32,52,72,77,79,80])$. Other methods exist also, such as utilization of vehicle-mounted instruments [81] and experiments where the instrumentation has been installed into a trailer and the exhaust is sam- pled from the exhaust plume of the studied vehicle [82].

The key compound in the formation of new nanosized particles in the exhaust cooling process seems to be sulfuric acid formed to exhaust by oxidation of fuel and lubricant oil originated sulfur [83-85]. Thus, the sulfur contents of lubricant oil and fuel affects the formation of nanoparticles [77, 86-88]. In addition, oxidative exhaust after-treatment devices that are very typically used in modern devices tend to increase the formation rate of these exhaust plume nanoparticles $[32,86,87]$ because they oxidize the engine out sulfur dioxide to sulfur trioxide that reacts with exhaust's water and form gaseous sulfuric acid [85].

It should be noted that although sulfuric acid is observed to be a key compound in nanoparticle formation of cooling exhaust, other exhaust compounds can also contribute to the process. For example, the mass spectrometry studies of Arnold et al. [85] and modelling studies $[89,90]$ have indicated that exhaust also contains low volatile organic compounds that can contribute to the nucleation processes. In the study of Karjalainen et al. [91], the nanoparticle emission of a diesel engine was even inversely correlated with exhaust sulfuric acid concentration during the regeneration of soot accumulated to partial DPF, although the modelling study of $\mathrm{Du}$ and $\mathrm{Yu}$ [84] indicated that in the regeneration process the sulfate stored and then released to the exhaust can lead to elevated nanoparticle emission. In addition, it is known that the organic compounds of exhaust contribute to nanoparticle formation by condensing onto the particle surfaces and thus by increasing the size of particles [52]. Regarding diesel exhaust, the majority of the mass of these particles can originate from lubricant oil (79-92\% in the study of Fushimi et al. [59]), and most of that mass comes from organic compounds of lubricant oil. However, hydrocarbons of gasoline vehicle exhaust particles seem to originate more from fuel than from lubricant oil [70, 74].

Although the information on the chemical composition of the smallest exhaust particles is limited, nanoparticles formed during the cooling dilution of exhaust seem to have significantly different chemical and physical characteristics when compared to particles formed in high temperatures. Most importantly, the volatility of "liquid-like" particles formed during the cooling dilution is higher than that of "solid" particles formed in high temperatures [55]. This leads to the possibility that the particles formed during the cooling dilution of exhaust can evaporate or even dis- 
appear when the particles are aged in the atmosphere [92]. Different chemical and physical characteristics of nanoparticles may also have implications for the effects of the particles on human health and on the mechanisms of how they affect human health. When the particles are deposited onto the epithelium of the human respiratory track, the nanoparticles formed during cooling dilution and consisting of sulfuric acid, hydrocarbons, and water may be dissolved more efficiently than the nanoparticles formed in high temperatures and consisting of metallic compounds and/or solid carbonaceous compounds. This may have implications on how the particles exist in human body, how they move from deposition site to other organs, and how they affect the functions of cells and organs.

Although the delayed primary aerosol formation, i.e., the formation of particulate matter during exhaust cooling and dilution from hot exhaust's gaseous compounds, is dependent on technological parameters of vehicles (fuel and lubricant oil sulfur, exhaust aftertreatment devices), climatic conditions and existing ambient aerosol may also affect its formation. In particular, the formation of new nanoparticles during the exhaust's cooling may be affected by these factors [29, 32]. Cold weather conditions seem to favor nanoparticle formation in atmospheric vehicle exhaust and, at least based on the modeling studies, also the relative humidity of ambient air affects the nanoparticle formation. However, the study of Casati et al. [77] made for a diesel passenger car did not observed significant differences between exhaust plume nanoparticle concentrations and size distributions when the ambient temperature changed from $9^{\circ} \mathrm{C}$ to $25^{\circ} \mathrm{C}$.

\section{NANOPARTICLES IN ROADSIDE ENVIRONMENTS}

The particle number size distribution of roadside environments is very typically reported to be dominated by nanoparticles [19, 20, 76, 92-94]. This observation is linked mostly to exhaust emissions of traffic, so that the high nanoparticle concentrations are a result of all fresh emissions [30], i.e., emissions of primary sub-10 $\mathrm{nm}$ nanoparticles (core particles), soot mode particles, and particles formed in cooling dilution of exhaust. Also, the particles formed in motoring conditions containing metallic lubricant oil originated compounds $[66,67]$ should be present in roadside environment because they significantly contribute to the vehicle exhaust nanoparticle emissions. For instance, in the study of Al-Dabbous and Kumar [30], the contribution of fresh traffic emissions to particle number concentration in roadside environment was $46 \%$, while the contributions of aged traffic emissions, industrial emissions, and regional background were $27 \%, 9 \%$, and $9 \%$, respectively. In that study, the contribution of aged traffic emissions on nanoparticle concentrations was also significant but, however, to the slightly larger particle sizes; the fresh traffic emission was a dominating source for particles smaller than 10 , while the aged traffic emission was a dominating source of $10-30 \mathrm{~nm}$ particles. The particle size distribution associated with fresh traffic emissions had a major peak (particle mode) in $5-12 \mathrm{~nm}$ and a minor peak at approximately $60 \mathrm{~nm}$, being thus highly similar with typical exhaust particle size distributions measured for individual vehicles. The importance of road traffic emissions was also seen in the analyses of particle concentration data from urban background site of Barcelona [95]; contributions from $52 \%$ to $86 \%$ of the particle number in the different particle sizes were associated with fresh emissions of relatively nearby traffic, and $5-33 \%$ to background aerosol that also was partly affected by traffic.

Barone and Zhu [96] measured the particle number size distribution at different distances from busy road and, in line with Al-Dabbous and Kumar [30] and Virtanen et al. [94], observed that it consisted of separate modes. On the road, the particle size distribution was dominated by the mode with geometric mean diameter of $14.3 \mathrm{~nm}$, but when the distance from the road increased, the relative contribution of particles in this size decreased; at $90 \mathrm{~m}$ from the road, the particle number size distribution was dominated by the mode with geometric mean particle size of $35.9 \mathrm{~nm}$. The increase of particle size as a function of increased distance from the road was also observed in mobile laboratory measurements reported by Pirjola et al. [97], but, however, in their study, the particle size increase was relatively small; in wintertime, the mean diameter of nanoparticle mode (called nucleation mode in the study) increased from $16.6 \mathrm{~nm}$ to $22.7 \mathrm{~nm}$ when the distance from road increased from $9 \mathrm{~m}$ to $80 \mathrm{~nm}$. Simultaneously, the mean size of the accumulation mode did not change. In summertime, the changes in mean size of nanoparticles were smaller and, despite the decreased number concentration, no significant transformation of particle size distribution was observed as a function of distance from the road. In principle, the differences of 
the growth of the particles for the two seasons can be explained by more efficient condensation of emitted semivolatile compounds in cold conditions or by larger semivolatile compound emissions of traffic in wintertime.

Although the nanoparticle concentration and particle number size distribution in traffic-influenced environments is typically controlled by traffic volume of near-by roads (see, e.g., [20]), they are also affected by weather conditions. Especially the wind direction affects the concentrations; higher concentrations exist typically downwind rather than upwind directions from the road. The studies of Charron and Harrison [76], Kittelson et al. [29], Pirjola et al. [97], and Virtanen et al. [94] reported higher nanoparticle concentrations in lower ambient temperatures, and associate this observation with enhanced atmospheric nanoparticle formation from traffic emitted gaseous compounds. In the recent roadside study for number concentrations of particles larger than $10 \mathrm{~nm}$, the season average particle emission factor determined for the traffic was a factor of 3 higher in winter than in summer $\left(7.5 \pm 5 \times 10^{14}\right.$ particles per $\mathrm{kg}$ of fuel versus $2.5 \pm 1.7 \times 10^{14}$ particles per $\mathrm{kg}$ of fuel) [98]. Also, in that study the particle size distribution of roadside aerosol was dominated by nanoparticles, both in winter and in summer. However, in wintertime the mean size of particles was larger, approximately $15-20 \mathrm{~nm}$, while in summertime, the peak concentrations were close to $10 \mathrm{~nm}$ particle size, which was the smallest size measured. The emission factors reported by Saha et al. [98] are in-line with earlier roadside measurement; e.g., the roadside particle study of Pirjola et al. [97] reported 1.8-3.4 times higher particle number concentrations in winter than in summer. In summer, 86-90\% and 90-95\% of particles larger than $3 \mathrm{~nm}$ belonged to sub-50 nm particle size range in summer and winter, respectively.

It should be noted that the lower size limit of roadside particle measurement is important parameter and should be taken into account in interpretation of results. This has been observed in recent studies where the lower size limit has been set so that the nanoclusters can also be counted [19, 20]. These studies indicate a very large contribution of sub $10 \mathrm{~nm}$ particles to the total particle number of roadside aerosol and significant (in certain environments even larger than $50 \%$ of total particle number) contribution of sub $3 \mathrm{~nm}$ particles.

Rainy weather conditions have been reported to reduce the roadside air nanoparticle concentrations
[34], although such weather condition may have opposite effects also; rainy weather clean urban air reducing the condensation sink formed by particles which can lead to increased concentrations of nanoparticles in roadside environment. Such phenomenon can be seen in the study of Charron and Harrison [76], which reported higher nanoparticle concentrations at roadside environments just after the rain event compared to the situation several days after the event.

The roadside aerosol has been reported to be mixed both externally and internally; in the externally mixed aerosol, the composition of individual particles can be distinctly different from other particles, while in internally mixed aerosol, individual particles consist of mixtures of different compounds. Examples of these can be found, e.g., from the study of Barone and Zhu [96] where they, in addition to particle size distribution measurements, sampled particles with mobility diameter of $50 \mathrm{~nm}$ and analyzed them by transmission electron microscope (TEM). They classified the particles according to particles' morphology and reported several different types of particles; the observed particles were aggregates, spheres, or they were irregularly shaped and some fraction of particles included a combination of these aforementioned different particle types. The particles associated with traffic emissions were internally mixed. Also, the fraction of particles with different morphologies of $50 \mathrm{~nm}$ particles changed when the distance from road increased; in their study, the fraction of aggregate particles decreased simultaneously with the increasing fraction of particles with multiple inclusions.

The diversity of the particle morphologies is higher in roadside ambient aerosol if compared to the exhaust of an individual vehicle. This was observed in the study of Fujitani et al. [61] where the roadside nanoparticles (mobility diameters $30 \mathrm{~nm}$ and $50 \mathrm{~nm}$ ) were studied by TEM and classified according to the particles' morphologies, electron opacity, electron transparency, and based on the partial evaporation of particles under the electron beam of TEM. In mobility sizes of $30 \mathrm{~nm}$ and $50 \mathrm{~nm}$, the roadside aerosol contained electronopaque particles, irregularly shaped electron-opaque particles, irregularly shaped electron-transparent particles, irregularly shaped partially evaporated particles, bar-like electron-opaque particles, bar-like electron-transparent particle, and electron-opaque agglomerated particles. In diesel engine exhaust, the nanoparticle population in these particle sizes was 
strongly dominated by electron-opaque agglomerated particles, which are presumably soot particles containing elemental carbon and organic compounds on their surfaces. During idle, they observed irregularly shaped particles.

Recent roadside aerosol studies have also revealed the existence of iron-rich nanoparticles in the roadside environment [42]. In total, the roadside aerosol is mixed both externally and internally, so that it contains physically and chemically different particles and that the individual particles are not always homogeneous. This can be seen in the study of Barone et al. [96], which reported "electron-opaque" particles having different morphologies (aggregates, spheres, irregularly shaped) to be in roadside aerosol and that those were encapsulated by an electron-transparent material. The spherical particle morphology was observed also in iron-rich particles reported by Sanderson et al. [42]. In addition to particles found in TEM studies by Barone et al. [96] and Sanderson et al. [42], the particle population contain nanoparticles containing semi-volatile compounds. These compounds cannot be observed by TEM analyses because they evaporate during the analyzing procedure.

Regarding the organic compounds of nanoparticles, Fushimi et al. [99] applied a thermal desorption-GC/MS to nanoparticles of roadside atmosphere. They observed that the chromatogram patterns of the roadside nanoparticles (particle size range $29 \mathrm{~nm}-58 \mathrm{~nm}$ ) matched better with patterns determined for lubricant oil than with patterns for fuel or diesel exhaust PM. They also observed that the fraction of less volatile compounds was larger in nanoparticles than in lubricant oil, which suggests that the most volatile organic compounds may exist more in a gaseous phase in the atmosphere. This was supported by their other study [100] where they, in addition, suggest that the OC/TC is higher for roadside nanoparticles than for particles in typical diesel exhaust soot particle size range. Roadside nanoparticles also contain inorganic semivolatile compounds, as reported by Lin et al. [101]. They observed significantly larger mass factions of ammonium, nitrate, and sulfate in nanoparticle size range when those were compared with the concentrations of these compounds in rural site nanoparticles.

In general, the studies conducted in proximity of road traffic indicate that the majority of nanoparticles are primary or delayed primary emissions from traffic. When dispersed to surroundings (see [97]), these emissions can affect the nanoparticle loadings of an urban atmosphere in relatively large areas; e.g., the recent study focusing on the dispersion of traffic emitted pollutants indicated that even the smallest particles can increase in size already in immediate proximity of traffic [102], which may significantly increase their atmospheric lifetime. However, in addition to primary and delayed primary particles, the exhaust from internal combustion engines contains gaseous pollutants that deteriorate the air quality in traffic influenced environments. Part of these compounds has a potential to form particulate matter in the atmosphere after they has been exposed to oxidizing atmospheric conditions. This process is called secondary particulate matter formation, and it results in the increased amount of oxidized organic compounds, nitrate, ammonium, and sulfate in atmospheric PM. As a result of the atmospheric secondary PM formation, new nano-sized particles can also be formed (see [103]) and the directly emitted particles can increase in size and their surface properties can change. It should be noted that the effects of secondary PM on human health can be significantly different when compared to primary emissions of traffic. This is due to the differences in composition, physical characteristics, particle size, concentrations, and spatial distribution of primary and secondary PM. A relatively detailed example of these differences is found by Klems et al. [104] who observed that the particles containing oxidized carbonaceous matter, typically linked with secondary PM formation, are generally neutralized, whereas particles containing unoxidized carbonaceous matter or no carbon at all are acidic.

Vehicle technologies affect the secondary PM precursor emissions and significant differences can exist in the emissions, depending on engine type, fuel characteristics, and exhaust after-treatment systems (reviewed in [105]). In the study of Timonen et al. [74], the change of low ethanol content gasoline to $100 \%$ ethanol decreased drastically the secondary PM precursor emissions. Regarding diesel vehicles, the exhaust after-treatment devices seems to also affect these emission components and, in general, natural gas fueled engines seems to be low-emitters in respect to secondary PM precursors [105]. Thus, because different technologies are favored in different geographical areas due to the non-uniform emission regulations, the contribution of traffic to atmospheric secondary nanoparticle formation can vary. In addition, it should be noted that the climatic conditions also contribute to the secondary PM formation in urban atmospheres. 
Table 1

Typical sizes, number concentrations, and compositions of nanoparticles in tailpipe, roadside, and aged exhaust aerosol

\begin{tabular}{|c|c|c|c|}
\hline & Primary exhaust particles & Roadside exhaust particles & $\begin{array}{l}\text { Atmospherically aged exhaust } \\
\text { particles }\end{array}$ \\
\hline Particle size & $\begin{array}{l}\text { Strongly affected by techniques } \\
\text { used in vehicle. Number size } \\
\text { distribution typically } \\
\text { dominated by sub- } 50 \mathrm{~nm} \\
\text { particles, frequently even by } \\
\text { sub-10 nm particles. }\end{array}$ & $\begin{array}{l}\text { Number size distribution } \\
\text { typically dominated by sub-50 } \\
\text { nm particles. Affected by type } \\
\text { and number of vehicles on } \\
\text { closest roads, as well as } \\
\text { environmental factors } \\
\text { (background aerosol, nearby } \\
\text { buildings, wind direction, } \\
\text { weather, etc.) }\end{array}$ & $\begin{array}{l}\text { No clear data exist on the role of } \\
\text { traffic in secondary new } \\
\text { particle formation. } \\
\text { Condensation of secondary } \\
\text { organic and inorganic species } \\
\text { may increase the particle size } \\
\text { when compared to initially } \\
\text { emitted particles. }\end{array}$ \\
\hline Particle number concentration & $\begin{array}{l}\text { Typically from }<10^{2} \text { to } 10^{8} \mathrm{~cm}^{-3} \text {, } \\
\text { depending, e.g., on engine } \\
\text { type, fuel, lubricant oil and } \\
\text { exhaust after-treatment. }\end{array}$ & $\begin{array}{l}\text { Typically } 10^{4}-10^{5} \mathrm{~cm}^{-3} \text {, in some } \\
\text { situations lower (clean } \\
\text { background aerosol, wind not } \\
\text { directly from road) or higher } \\
\text { (e.g., instantaneous effects of } \\
\text { high emitters). }\end{array}$ & $\begin{array}{l}\text { Traffic exhaust originated } \\
\text { particles are mixed with } \\
\text { particles from other sources. } \\
\text { No clear data on number of } \\
\text { traffic exhaust originated } \\
\text { particle number. }\end{array}$ \\
\hline Particle composition & $\begin{array}{l}\text { Soot consisting of elemental } \\
\text { carbon and metallic } \\
\text { compounds; metallic ash } \\
\text { particles. Composition of } \\
\text { smallest particles partly } \\
\text { unknown. }\end{array}$ & $\begin{array}{l}\text { Primary exhaust particles: } \\
\text { Elemental carbon, metallic ash. } \\
\text { Iron rich particles, sulfate, } \\
\text { nitrate, hydrocarbons and other } \\
\text { organic compounds. }\end{array}$ & $\begin{array}{l}\text { Traffic exhaust originated } \\
\text { compounds are mixed with } \\
\text { particles from other sources. } \\
\text { Aged soot and other primary } \\
\text { particles. Sulfate, nitrate, } \\
\text { organic compounds. }\end{array}$ \\
\hline
\end{tabular}

Note that the values and compositions are indicative only and they can vary significantly.

\section{RESEARCH NEEDS}

Although nanoparticle measurements have significantly developed during recent years enabling online measurements of even the smallest nanoparticles, the largest challenge is that while nanosized particles exist in large number concentrations, their mass is almost negligible. In order to characterize the health and environmental impacts of nanoparticles, further research is needed on 1) nanoparticles; their composition and sources (e.g., atmospheric nucleation versus directly emitted nanoparticles), their formation mechanisms, and their transformation in the atmosphere; 2) how the nanoparticles are transported to human body, i.e., what are the transportation routes, how effectively are they transported, and how long is the lifetime of nanoparticles in the human body; 3 ) impacts of nanoparticles on human health, i.e., what diseases are affected by nanoparticle pollution and what are the mechanisms causing these diseases at the organ and cellular levels. To achieve these targets, novel methodologies are needed both to characterize nanoparticles and their composition and to study their health and toxicological impacts. The challenge of future studies is to characterize whether nanoparticle number concentrations, particle mass, or particle surface area is the important parameter when health effects are studied; e.g., Schmid and Stoeger
[106] have compared different particle-related metrics in respect to pulmonary toxicity of particles, recommending that measurements should take particle number, surface area, and mass into account but that, based on their study, the most important parameter seems to be the surface area of particles. Metrics for the health effects of exhaust particles have also been studied by Giechaskiel et al. [107] who divides the effects of particles to physical effects, caused mainly by active surface area of soot particles, and chemical effects, caused by the semivolatile compounds condensed on solid particle surfaces. Nonetheless, the long-term monitoring of ambient nanoparticle concentrations and their characteristics in urban areas are needed to connect their existence and effects to epidemiological studies.

Regarding the role of nanoparticles in Alzheimer's disease, more emphasis should be paid to connect the results from toxicological studies with studies focusing on anthropogenic nanoparticle emissions and ambient nanoparticles. For instance, more data on characteristics (composition, morphology, and size distribution) of particles found in the human body and especially in the human brain could significantly help determine the sources of these particles. In addition, that kind of data could help to evaluate the particle transportation from epithelium to brain and other organs and, importantly, to enable 
more efficient development of nanoparticle emission mitigation, both in policy and mitigation technology development point of views.

\section{CONCLUSIONS}

It is important to note that the studies of ambient air conducted at road-traffic influenced environments report repeatedly very high nanoparticle concentrations. These environments are typical for all urban areas, and they represent normal living environments for millions of people, and for many of us, a working environment too. Thus, it can be concluded that a very large number of people are exposed to large numbers of atmospheric traffic-originated nanoparticles in their everyday life.

Measurements indicate that the nanoparticles of roadside atmosphere are emitted by gasoline vehicles, diesel vehicles, and by vehicles using ethanol and gaseous fuels. In addition, nanoparticles are emitted from wheel brakes and formed from initially gaseous exhaust compounds. Thus, the possible problems caused by nanoparticles cannot be solved straightforwardly, e.g., by focusing on one type of vehicles or engines. On the other hand, many technological solutions clearly decrease the nanoparticle emissions of motor vehicles, such as low-sulfur fuels and diesel particle filters, and these technologies should be favored when developing emission regulations and air quality standards to protect people from nanoparticle exposures.

Nanoparticles of urban air in traffic-influenced environments (see Table 1) are not uniform but, instead, they form an externally and internally mixed aerosol with large variation of particle characteristics. This is important to take into account in evaluation of their effects on human health.

\section{DISCLOSURE STATEMENT}

Authors' disclosures available online (https:// www.j-alz.com/manuscript-disclosures/19-0170r2).

\section{REFERENCES}

[1] Pope CA, Dockery DW (2006) Health effects of fine particulate air pollution: Lines that connect. J Air Waste Manag Assoc 56, 709-742.

[2] Zimmermann R (2011) Ambient aerosols and human health: Working towards a combined analytical and toxicological approach. Anal Bioanal Chem 401, 3041-3044.
[3] Davidson CI, Phalen RF, Solomon PA (2005) Airborne particulate matter and human health: A review. Aerosol Sci Tech 39, 737-749.

[4] Hoek G, Krishnan RM, Beelen R, Peters A, Ostro B, Brunekreef B, Kaufman JD (2013) Long-term air pollution exposure and cardio-respiratory mortality: A review. Environ Health 12, 43.

[5] Pieters N, Koppen G, Van Poppel M, De Prins S, Cox B, Dons E, Nelen V, Panis LI, Plusquin M, Schoeters G, Nawrot TS (2015) Blood pressure and same-day exposure to air pollution at school: Associations with nano-sized to coarse PM in children. Environ Health Persp 123, 737-742.

[6] Lelieveld J, Evans JS, Fnais M, Giannadaki D, Pozzer A (2015) The contribution of outdoor air pollution sources to premature mortality on a global scale. Nature 525, 367371.

[7] Jung CR, Lin YT, Hwang BF (2015) Ozone, particulate matter, and newly diagnosed Alzheimer's disease: A population-based cohort study in Taiwan. JAlzheimers Dis 44, 573-584.

[8] Cacciottolo M, Wang X, Driscoll I, Woodward N, Saffari A, Reyes J, Serre ML, Vizuete W, Sioutas C, Morgan TE, Gatz M, Chui HC, Shumaker SA, Resnick SM, Espeland MA, Finch CE, Chen JC (2017) Particulate air pollutants, APOE alleles and their contributions to cognitive impairment in older women and to amyloidogenesis in experimental models. Transl Psychiat 7, e1022.

[9] Hinds WC (1999) Aerosol Technology, Properties, Behaviour, and Measurement of Airborne Particles. John Wiley \& Sons Inc., New York.

[10] Calderón-Garcidueñas L, González-Maciel A, ReynosoRobles R, Kulesza RJ, Mukherjee PS, Torres-Jardón R, Rönkkö T, Doty RL (2018) Alzheimer's disease and alphasynuclein pathology in the olfactory bulbs of infants, children, teens and adults $\leq 40$ years in Metropolitan Mexico City. APOE4 carriers at higher risk of suicide accelerate their olfactory bulb pathology. Environ Res $\mathbf{1 6 6}$, 348-362.

[11] Maher BA, Ahmed IAM, Karloukovski V, MacLaren DA, Foulds PG, Allsop D, Mann DMA, Torres-Jardón R, Calderon-Garciduenas L (2016) Magnetite pollution nanoparticles in the human brain. Proc Natl Acad Sci U S A 113, 10797-10801.

[12] Kim SH, Knight EM, Saunders EL, Cuevas AK, Popovech M, Chen LC, Gandy S (2012) Rapid doubling of Alzheimer's amyloid-beta 40 and 42 levels in brains of mice exposed to a nickel nanoparticle model of air pollution. F1000Research 1, 70.

[13] Plascencia-Villa G, Ponce A, Collingwood JF, ArellanoJiménez JM, Zhu X, Rogers JT, Betancourt I, JoséYacamán M, Perry G (2016) High-resolution analytical imaging and electron holography of magnetite particles in amyloid cores of Alzheimer's disease. Sci Rep 6, 24873.

[14] Power MC, Weisskopf MG, Alexeeff SE, Coull BA, Avron III S, Schwartz J (2011) Traffic-related air pollution and cognitive function in a cohort of older men. Environ Health Persp 119, 682-687.

[15] Zhang X, Chen X, Zhang X (2018) The impact of exposure to air pollution on cognitive performance. Proc Natl Acad Sci U S A 115, 9193-9197.

[16] Oudin A, Forsberg B, Adolfsson AN, Lind N, Modig L, Nordin M, Nordin S, Adolfsson R, Nilsson L-G (2016) Traffic-related air pollution and dementia incidence in Northern Sweden: A longitudinal study. Environ Health Persp 124, 306-312. 
[17] Brines M, Dall'Osto M, Beddows D, Harrison R, GómezMoreno F, Núñez L, Artínano B, Costabile F, Gobbi G, Salimi F, Morawska L, Sioutas C, Querol X (2015) Traffic and nucleation events as main sources of ultrafine particles in high-insolation developed world cities. Atmos Chem Phys 15, 5929-5945.

[18] Hussein T, Puustinen A, Aalto PP, Mäkelä JM, Hämeri K, Kulmala M (2004) Urban aerosol number size distributions. Atmos Chem Phys 4, 391-411.

[19] Rönkkö T, Kuuluvainen H, Karjalainen P, Keskinen J, Hillamo R, Niemi JV, Pirjola L, Timonen HJ, Saarikoski S, Saukko E, Järvinen A, Silvennoinen H, Rostedt A, Olin M, Yli-Ojanperä J, Nousiainen P, Kousa A, Dal Maso M (2017) Traffic is a major source of atmospheric nanocluster aerosol. Proc Natl Acad Sci U S A 114, 7549-7554.

[20] Hietikko R, Kuuluvainen H, Harrison RM, Portin H, Timonen H, Niemi JV, Rönkkö T (2018) Diurnal variation of nanocluster aerosol concentrations and emission factors in a street canyon. Atmos Environ 189, 98-106.

[21] Carbone S, Saarikoski S, Frey A, Reyes F, Reyes P, Castillo M, Gramsch E, Oyola P, Jayne J, Worsnop DR, Hillamo R (2013) Chemical characterization of submicron aerosol particles in Santiago de Chile. Aerosol Air Qual Res 13, 462-473.

[22] Crippa M, Canonaco F, Lanz VA, Äijälä M, Allan JD, Carbone S, Capes G, Ceburnis D, Dall'Osto M, Day DA, DeCarlo PF, Ehn M, Eriksson A, Freney E, Hildebrandt RL, Hillamo R, Jimenez JL, Junninen H, Kiendler-Scharr A, Kortelainen A-M, Kulmala M, Laaksonen A, Mensah AA, Mohr C, Nemitz E, O'Dowd C, Ovadnevaite J, Pandis SN, Petäjä T, Poulain L, Saarikoski S, Sellegri K, Swietlicki E, Tiitta P, Worsnop DR, Baltensperger U, Prévôt AS (2014) Organic aerosol components derived from 25 AMS data sets across Europe using a consistent ME-2 based source apportionment approach. Atmos Chem Phys 14, 6159-6176.

[23] Pirjola L, Niemi JV, Saarikoski S, Aurela M, Enroth J, Carbone S, Kuuluvainen H, Kousa A, Rönkkö T, Hillamo R (2017) Physical and chemical characterization of urban winter-time aerosols by mobile measurements in Helsinki, Finland. Atmos Environ 158, 60-75.

[24] Robinson AL, Donahue NM, Shrivastava MK, Weitkamp EA, Sage AM, Grieshop AP, Lane TE, Pierce JR, Pandis SN (2007) Rethinking organic aerosols: Semivolatile emissions and photochemical aging. Science 315, 12591262.

[25] Jimenez JL, Canagaratna MR, Donahue NM, Prevot AS, Zhang Q, Kroll JH, DeCarlo PF, Allan JD, Coe H, Ng NL, Aiken AC, Docherty KS, Ulbrich IM, Grieshop AP, Robinson, AL, Duplissy J, Smith JD, Wilson KR, Lanz VA, Hueglin C, Sun YL, Tian J, Laaksonen A, Raatikainen T, Rautiainen J, Vaattovaara P, Ehn M, Kulmala M, Tomlinson JM, Collins DR, Cubison MJ, Dunlea EJ, Huffman JA, Onasch TB, Alfarra MR, Williams PI, Bower K, Kondo Y, Schneider J, Drewnick F, Borrmann S, Weimer S, Demerjian K, Salcedo D, Cottrell L, Griffin R, Takami A, Miyoshi T, Hatakeyama S, Shimono A, Sun JY, Zhang YM, Dzepina K, Kimmel JR, Sueper D, Jayne JT, Herndon SC, Trimborn AM, Williams LR, Wood EC, Middlebrook AM, Kolb CE, Baltensperger U, Worsnop DR (2009) Evolution of organic aerosols in the atmosphere. Science 326, 1525-1529.

[26] Ketzel M, Berkowicz R (2004) Modelling the fate of ultrafine particles from exhaust pipe to rural background: An analysis of time scales for dilution, coagulation and deposition. Atmos Environ 38, 2639-2652.

[27] Karl M, Kukkonen J, Keuken MP, Lützenkirchen S, Pirjola L, Hussein T (2016) Modeling and measurements of urban aerosol processes on the neighborhood scale in Rotterdam, Oslo and Helsinki. Atmos Chem Phys 16, 4817-4835.

[28] Baldauf R, Devlin R, Gehr P, Giannelli R, Hassett-Sipple B, Jung H, Martini G, McDonald J, Sacks J, Walker K (2016) Ultrafine particle metrics and research considerations: Review of the 2015 UFP Workshop. Int J Environ Res Pub Health 13, E1054.

[29] Kittelson DB, Watts WF, Johnson JP (2003) Nanoparticle emissions on Minnesota highways. Atmos Environ 38, 919.

[30] Al-Dabbous AN, Kumar P (2015) Source apportionment of airborne nanoparticles in a Middle Eastern city using positive matrix factorization. Environ Sci Process Impacts 17, 802-812.

[31] Giechaskiel B, Ntziachristos L, Samaras Z, Scheer V, Casati R, Vogt R (2005) Formation potential of vehicle exhaust nucleation mode particles on-road and in the laboratory. Atmos Environ 39, 3191-3198.

[32] Rönkkö T, Virtanen A, Vaaraslahti K, Keskinen J, Pirjola L, Lappi M (2006) Effect of dilution conditions and driving parameters on nucleation mode particles in diesel exhaust: Laboratory and on-road study. Atmos Environ 40, 28932901.

[33] Rönkkö T, Lähde T, Heikkilä J, Pirjola L, Bauchke U, Arnold F, Rothe D, Yli-Ojanperä J, Keskinen J (2013) Effects of gaseous sulphuric acid on diesel exhaust nanoparticle formation and characteristics. Environ Sci Technol 47, 11882-11889.

[34] Ntziachristos L, Ning Z, Geller MD, Sioutas C (2007) Particle concentration and characteristics near a major freeway with heavy-duty diesel traffic. Environ Sci Technol 41, 2223-2230.

[35] Alanen J, Saukko E, Lehtoranta K, Murtonen T, Timonen H, Hillamo R, Karjalainen P, Kuuluvainen H, Harra J, Keskinen J, Rönkkö T (2015) The formation and physical properties of the particle emissions from a natural gas engine. Fuel 162, 155-161.

[36] Pirjola L, Rönkkö T, Saukko E, Parviainen H, Malinen A, Alanen J, Saveljeff H (2017) Exhaust emissions of nonroad mobile machine: Real-world and laboratory studies with diesel and HVO fuels. Fuel 202, 154-164.

[37] Weimer S, Mohr C, Richter R, Keller J, Mohr M, Prévôt ASH, Baltensperger U (2009) Mobile measurements of aerosol number and volume size distributions in an Alpine valley: Influence of traffic versus wood burning. Atmos Environ 43, 624-630.

[38] Mylläri F, Karjalainen P, Taipale R, Aalto P, Häyrinen A, Rautiainen P, Pirjola L, Hillamo R, Keskinen J, Rönkkö T (2017) Physical and chemical characteristics of flue-gas particles in a large pulverized fuel-fired power plant boiler during co-combustion of coal and wood pellets. Combust Flame 176, 554-566.

[39] Mylläri F, Pirjola L, Lihavainen H, Asmi E, Saukko E, Laurila T, Vakkari V, O'Connor E, Rautiainen J, Häyrinen A, Niemelä V, Maunula J, Hillamo R, Keskinen J, Rönkkö $T$ (2018) Characteristics of particle emissions and their atmospheric dilution during co-combustion of coal and wood pellets in a large combined heat and power plant. $J$ Air Waste Manage Assoc 69, 97-108. 
[40] Happonen M, Mylläri F, Karjalainen P, Frey A, Saarikoski S, Carbone S, Hillamo R, Pirjola L, Häyrinen A, Kytömäki J, Niemi J, Keskinen J, Rönkkö T (2013) Size distribution, chemical composition, and hygroscopicity of fine particles emitted from an oil-fired heating plant. Environ Sci Technol 47, 14468-14475.

[41] Nosko O, Vanhanen J, Olofsson U (2017) Emission of 1.3-10 nm airborne particles from brake materials. Aerosol Sci Tech 51, 91-96.

[42] Sanderson P, Su SS, Chang ITH, Delgado Saborit JM, Kepaptsoglou DM, Weber RJM, Harrison RM (2016) Characterisation of iron-rich atmospheric submicrometre particles in the roadside environment. Atmos Environ 140, 167-175.

[43] Kulmala M, Kontkanen J, Junninen H, Lehtipalo K, Manninen HE, Nieminen T, Petäjä T, Sipilä M, Schobesberger S, Rantala P, Franchin A, Jokinen T, Järvinen E, Äijälä M, Kangasluoma J, Hakala J, Aalto PP, Paasonen P, Mikkilä J, Vanhanen J, Aalto J, Hakola H, Makkonen U, Ruuskanen T, Mauldin RL, Duplissy J, Vehkamäki H, Bäck J, Kortelainen A, Riipinen I, Kurtén T, Johnston MV, Smith JN, Ehn M, Mentel TF, Lehtinen KEJ, Laaksonen A, Kerminen V-M, Worsnop DR (2013) Direct observations of atmospheric aerosol nucleation. Science 339, 943-946.

[44] Saha PK, Robinson ES, Shah RU, Zimmerman N, Apte JS, Robinson AL, Presto AA (2018) Reduced ultrafine particle concentration in urban air: Changes in nucleation and anthropogenic emissions. Environ Sci Tech 52, 67986806.

[45] Liu Z, Hu B, Zhang J, Yu Y, Wang Y (2016) Characteristics of aerosol size distributions and chemical compositions during wintertime pollution episodes in Beijing. Atmos Res 168, 1-12.

[46] Joodatnia P, Kumar P, Robins A (2013) The behaviour of traffic produced nanoparticles in a car cabin and resulting exposure rates. Atmos Environ 65, 40-51.

[47] Karjalainen P, Saari S, Kuuluvainen H, Kalliohaka T, Taipale A, Rönkkö T (2017) Performance of ventilation filtration technologies on characteristic traffic related aerosol down to nanocluster size. Aerosol Sci Tech 51, 1398-1408.

[48] Morawska L, Ristovski Z, Jayaratne ER, Keogh DU, Ling $X$ (2008) Ambient nano and ultrafine particles from motor vehicle emissions: Characteristics, ambient processing and implications on human exposure. Atmos Environ 42, 8113-8138.

[49] Giechaskiel B, Mamakos A, Andersson J, Dilara P, Martini G, Schindler W, Bergmann A (2012) Measurement of automotive nonvolatile particle number emissions within the European legislative framework: A review. Aerosol Sci Tech 46, 719-749.

[50] Kumar P, Morawska L, Birmili W, Paasonen P, Hu M, Kulmala M, Harrison RM, Norford L, Britter R (2014) Ultrafine particles in cities. Environ Int 66, 1-10.

[51] Kumar P, Patton AP, Durant JL, Frey HC (2018) A review of factors impacting exposure to PM 2.5, ultrafine particles and black carbon in Asian transport microenvironments. Atmos Environ 187, 301-316.

[52] Rönkkö T, Virtanen A, Kannosto J, Keskinen J, Lappi M, Pirjola L (2007) Nucleation mode particles with a nonvolatile core in the exhaust of a heavy duty diesel vehicle. Environ Sci Tech 41, 6384-6389.

[53] Harris S, Maricq M (2001) Signature size distributions for diesel and gasoline engine exhaust particulate matter. $J$ Aerosol Sci 32, 749-764.
[54] De Filippo A, Maricq MM (2008) Diesel nucleation mode particles: Semivolatile or solid? Environ Sci Tech 42, 79577962.

[55] Lähde T, Rönkkö T, Virtanen A, Schuck T, Pirjola L, Hämeri K, Kulmala M, Arnold F, Rothe D, Keskinen J (2009) Heavy duty diesel engine exhaust aerosol particle and ion measurements. Environ Sci Tech 43, 163-168.

[56] Heikkilä J, Virtanen A, Rönkkö T, Keskinen J, AakkoSaksa P, Murtonen T (2009) Nanoparticle emissions from a heavy-duty engine running on alternative diesel fuels. Environ Sci Tech 43, 9501-9506.

[57] Sgro LA, Sementa P, Vaglieco BM, Rusciano G, D'Anna A, Minutolo P (2012) Investigating the origin of nuclei particles in GDI engine exhausts. Combust Flame 159, 1687-1692.

[58] Seong H, Choi S, Lee K (2014) Examination of nanoparticles from gasoline direct-injection (GDI) engines using transmission electron microscopy (TEM). Int J Automot Techn 15, 175-181.

[59] Fushimi A, Saitoh K, Fujitani Y, Hasegawa S, Takahashi K, Tanabe K, Kobayashi S (2011) Organic-rich nanoparticles (diameter: 10-30 nm) in diesel exhaust: Fuel and oil contribution based on chemical composition. Atmos Environ 45, 6326-6336.

[60] Lähde T, Virtanen A, Happonen M, Söderström C, Kytö M, Keskinen J (2014) Heavy-duty, off-road diesel engine low-load particle number emissions and particle control. J Air Waste Manage Assoc 64, 1186-1194.

[61] Fujitani Y, Sakamoto T, Misawa K (2012) Quantitative determination of composition of particle type by morphology of nanoparticles in diesel exhaust and roadside atmosphere. J Civil Environ Eng S1, 002.

[62] Lähde T, Rönkkö T, Happonen M, Söderström C, Virtanen A, Solla A, Kytö M, Rothe D, Keskinen J (2011) Effect of fuel injection pressure on a heavy-duty diesel engine nonvolatile particle emission. Environ Sci Tech 45, 25042509.

[63] Lähde T, Rönkkö T, Virtanen A, Solla A, Kytö M, Söderström C, Keskinen J (2010) Dependence between nonvolatile nucleation mode particle and soot number concentrations in an EGR equipped heavy duty diesel engine exhaust. Environ Sci Tech 44, 3175-3180.

[64] Nousiainen P, Niemi S, Rönkkö T, Karjalainen P, Keskinen J, Kuuluvainen H, Pirjola L, Saveljeff H (2013) Effect of injection parameters on exhaust gaseous and nucleation mode particle emissions of a Tier $4 \mathrm{i}$ nonroad diesel engine. SAE Technical Papers, 2013-01-2575.

[65] Tree DR, Svensson KI (2007) Soot processes in compression ignition engines. Prog Energ Combust 33, 272-309.

[66] Rönkkö T, Pirjola L, Ntziachristos L, Heikkilä J, Karjalainen P, Hillamo R, Keskinen J (2014) Vehicle engines produce exhaust nanoparticles even when not fueled. Environ Sci Tech 48, 2043-2050.

[67] Karjalainen P, Ntziachristos L, Murtonen T, Wihersaari H, Simonen P, Mylläri F, Nylund N-O, Keskinen J, Rönkkö T (2016) Heavy duty diesel exhaust particles during engine motoring formed by lube oil consumption. Environ Sci Technol 50, 12504-12511.

[68] Liati A, Dimopoulos Eggenschwiler P, Müller Gubler E, Schreiber D, Aguirre M (2012) Investigation of diesel ash particulate matter: A scanning electron microscope and transmission electron microscope study. Atmos Environ 49, 391-402. 
[69] Puisney C, Oikonomou EK, Nowak S, Chevillot A, Casale S, Baeza-Squiban A, Berret JF (2018) Brake wear (nano)particle characterization and toxicity on airway epithelial cells in vitro. Environ Sci Nano 5, 1036-1044.

[70] Fushimi A, Kondo Y, Kobayashi S, Fujitani Y, Saitoh K, Takami A, Tanabe K (2016) Chemical composition and source of fine and nanoparticles from recent direct injection gasoline passenger cars: Effects of fuel and ambient temperature. Atmos Environ 124, 77-84.

[71] Karjalainen P, Rönkkö T, Lähde T, Rostedt A (2012) Reduction of heavy-duty diesel exhaust particle number and mass at low exhaust temperature driving by the DOC and the SCR. SAE Int J Fuels Lubr 5, 1114-1122.

[72] Lee SH, Kwak JH, Lee SY, Lee JH (2015) On-road chasing and laboratory measurements of exhaust particle emissions of diesel vehicles equipped with aftertreatment technologies (DPF, urea-SCR). Int J Automot Techn 16, 551-559.

[73] Heikkilä J, Rönkkö T, Lähde T, Lemmetty M, Arffman A, Virtanen A, Keskinen J, Pirjola L, Rothe D (2009) Effect of open channel filter on particle emissions of modern diesel engine. J Air Waste Manage Assoc 59, 1148-1154.

[74] Timonen H, Karjalainen P, Saukko E, Saarikoski S, Aakko-Saksa P, Simonen P, Murtonen T, Dal Maso M, Kuuluvainen H, Bloss M, Ahlberg E, Svenningsson B, Pagels J, Brune WH, Keskinen J, Worsnop DR, Hillamo R, Rönkkö T (2017) Influence of fuel ethanol content on primary emissions and secondary aerosol formation potential for a modern flex-fuel gasoline vehicle. Atmos Chem Phys 17, 5311-5329.

[75] Kittelson DB (1998) Engines and nanoparticles: A review. J Aerosol Sci 29, 575-588.

[76] Charron A, Harrison RM (2003) Primary particle formation from vehicle emissions during exhaust dilution in the roadside atmosphere. Atmos Environ 37, 4109-4119.

[77] Casati R, Scheer V, Vogt R, Benter T (2007) Measurement of nucleation and soot mode particle emission from a diesel passenger car in real world and laboratory in situ dilution. Atmos Environ 41, 2125-2135.

[78] Keskinen J, Rönkkö T (2010) Can real-world diesel exhaust particle size distribution be reproduced in the laboratory? A critical review. J Air Waste Manage Assoc 60, 1245-1255.

[79] Karjalainen P, Pirjola L, Heikkilä J, Lähde T, Tzamkiozis T, Ntziachristos L, Keskinen J, Rönkkö T (2014) Exhaust particles of modern gasoline vehicles: A laboratory and an on-road study. Atmos Environ 97, 262-270.

[80] Saari S, Karjalainen P, Ntziachristos L, Pirjola L, Matilainen P, Keskinen J, Rönkkö T (2016) Exhaust particle and NOx emission performance of an SCR heavy duty truck operating in real-world conditions. Atmos Environ 126, 136-144.

[81] Uhrner U, Zallinger M, von Löwis S, Vehkamäki H, Wehner B, Stratmann F, Wiedensohler A (2011) Volatile nanoparticle formation and growth within a diluting diesel car exhaust. J Air Waste Manage Assoc 61, 399-408.

[82] Morawska L, Ristovski ZD, Johnson GR, Jayaratne ER, Mengersen K (2007) Novel method for on-road emission factor measurements using a plume capture trailer. Environ Sci Tech 41, 574-579.

[83] Lemmetty M, Rönkkö T, Virtanen A, Keskinen J, Pirjola L (2008) The effect of sulphur in diesel exhaust aerosol: Models compared with measurements. Aerosol Sci Tech 42, 916-929.
[84] Du H, Yu F (2008) Nanoparticle formation in the exhaust of vehicles running on ultra-low sulfur fuel. Atmos Chem Phys 8, 4729-4739.

[85] Arnold F, Pirjola L, Rönkkö T, Reichl U, Schlager H, Lähde T, Heikkilä J, Keskinen J (2012) First on-line measurements of sulphuric acid gas in modern heavy duty diesel engine exhaust: Implications for nanoparticle formation. Environ Sci Tech 46, 11227-11234.

[86] Maricq MM, Chase RE, Xu N, Laing PM (2002) The effects of the catalytic converter and fuel sulfur level on motor vehicle particulate matter emissions: Light duty diesel vehicles. Environ Sci Tech 36, 283-289.

[87] Vaaraslahti K, Virtanen A, Ristimäki J, Keskinen J (2004) Nucleation mode formation in heavy-duty diesel exhaust with and without a particulate filter. Environ Sci Tech 38, 4884-4890.

[88] Vaaraslahti K, Keskinen J, Giechaskiel B, Solla A, Murtonen T, Vesala H (2005) Effect of lubricant on the formation of heavy-duty diesel exhaust nanoparticles. Environ Sci Tech 39, 8497-8504.

[89] Pirjola L, Karl M, Rönkkö T, Arnold F (2015) Model studies of volatile diesel exhaust particle formation: Are organic vapours involved in nucleation and growth? Atmos Chem Phys 15, 10435-10452.

[90] Olin M, Rönkkö T, Dal Maso M (2015) CFD modeling of a vehicle exhaust laboratory sampling system: Sulfurdriven nucleation and growth in diluting diesel exhaust. Atmos Chem Phys 15, 5305-5323.

[91] Karjalainen P, Rönkkö T, Pirjola L, Heikkilä J, Happonen M, Arnold F, Rothe D, Bielaczyc P, Keskinen J (2014) Sulfur driven nucleation mode formation in diesel exhaust under transient driving conditions. Environ Sci Tech 48, 2336-2343.

[92] Harrison RM, Dall'Osto M, Beddows DCS, Thorpe AJ, Bloss WJ, Allan JD, Coe H, Dorsey JR, Gallagher M, Martin C, Whitehead J, Williams PI, Jones RL, Langridge JM, Benton AK, Ball SM, Langford B, Hewitt CN, Davison B, Martin D, Petersson KF, Henshaw SJ, White IR, Shallcross DE, Barlow JF, Dunbar T, Davies F, Nemitz E, Phillips GJ, Helfter C, Di Marco CF, Smith S (2012) Atmospheric chemistry and physics in the atmosphere of a developed megacity (London): An overview of the REPARTEE experiment and its conclusions Atmos Chem Phys 12, 3065-3114.

[93] Harrison RM, Jones M, Collins G (1999) Measurements of the physical properties of particles in the urban atmosphere. Atmos Environ 33, 309-321.

[94] Virtanen A, Rönkkö T, Kannosto J, Ristimäki J, Mäkelä J, Keskinen J, Pakkanen T, Hillamo R, Pirjola L, Hämeri K (2006) Winter and summer time size distributions and densities of traffic related aerosol particles at a busy highway in Helsinki. Atmos Chem Phys 6, 2411-2421.

[95] Pey J, Querol X, Alastuey A, Rodríguez S, Putaud JP, Van Dingenen R (2009) Source apportionment of urban fine and ultra-fine particle number concentration in a Western Mediterranean city. Atmos Environ 43, 4407-4415.

[96] Barone TL, Zhu Y (2008) The morphology of ultrafine particles on and near major freeways. Atmos Environ 42, 6749-6758.

[97] Pirjola L, Paasonen P, Pfeiffer D, Hussein T, Hämeri K, Koskentalo T, Virtanen A, Rönkkö T, Keskinen J, Pakkanen T (2006) Dispersion of particles and trace gases nearby a city highway: Mobile laboratory measurements in Finland. Atmos Environ 40, 867-879. 
[98] Saha PK, Khlystov A, Snyder MG, Grieshop AP (2018) Characterization of air pollutant concentrations, fleet emission factors, and dispersion near a North Carolina interstate freeway across two seasons. Atmos Environ 177, 143-153.

[99] Fushimi A, Tanabe K, Hasegawa S, Kobayashi S (2007) Investigation of characterization method for nanoparticles in roadside atmosphere by thermal desorption-gas chromatography/mass spectrometry using a pyrolyzer. $S c i$ Total Environ 386, 83-92.

[100] Fushimi A, Hasegawa S, Takahashi K, Fujitani Y, Tanabe K, Kobayashi S (2008) Atmospheric fate of nuclei-mode particles estimated from the number concentrations and chemical composition of particles measured at roadside and background sites. Atmos Environ 42, 949-959.

[101] Lin C-C, Huang K-L, Chen S-J, Liu S-C, Tsai J-H, Lin Y-C, Lin W-Y (2009) NH4+, NO3-, and SO42- in roadside and rural size-resolved particles and transformation of $\mathrm{NO} 2 / \mathrm{SO} 2$ to nanoparticle-bound NO3-/SO42-. Atmos Environ 43, 2731-2736.

[102] Kangasniemi O, Kuuluvainen H, Heikkilä J, Pirjola L, Niemi JV, Timonen H, Saarikoski S, Rönkkö T, Dal Maso M (2019) Dispersion of traffic related nanocluster aerosol near a major road. Atmosphere 10, 309.
[103] Ahlm L, Liu S, Day DA, Russell LM, Weber R, Gentner DR, Goldstein AH, Digangi JP, Henry SB, Keutsch FN, Vandenboer TC, Markovic MZ, Murphy JG, Ren X, Scheller S (2012) Formation and growth of ultrafine particles from secondary sources in Bakersfield, California. $J$ Geophys Res Atmos 117, D00V08.

[104] Klems JP, Zordan CA, Pennington MR, Johnston MV (2012) Chemical composition of ambient nanoparticles on a particle-by-particle basis. Anal Chem 84, 2253-2259.

[105] Alanen J, Simonen P, Saarikoski S, Timonen H, Kangasniemi O, Saukko E, Hillamo R, Lehtoranta K, Murtonen T, Vesala H, Keskinen J, Rönkkö T (2017) Comparison of primary and secondary particle formation from natural gas engine exhaust and of their volatility characteristics. Atmos Chem Phys 17, 8739-8755.

[106] Schmid O, Stoeger T (2016) Surface area is the biologically most effective dose metric for acute nanoparticle toxicity in the lung. J Aerosol Sci 99, 133-143.

[107] Giechaskiel B, Alföldy B, Drossinos Y (2009) A metric for health effects studies of diesel exhaust particles. J Aerosol Sci 40, 639-651. 